\title{
The impact of a strong natural hypoxic event on the toadfish Aphos porosus in Coliumo Bay, south-central Chile
}

\author{
Impacto de un fuerte evento de hipoxia natural sobre el bagre de mar Aphos porosus \\ en Bahía Coliumo, centro-sur de Chile

\section{Eduardo Hernández-Miranda ${ }^{1}$, Renato A. Quiñones ${ }^{1,2,3}$, Gustavo Aedo ${ }^{3}$, Ernesto Díaz-Cabrera ${ }^{1}$ and José Cisterna ${ }^{1}$}

\author{
${ }^{1}$ Programa de Investigación Marina de Excelencia, Facultad de Ciencias Naturales y Oceanográficas, Universidad de \\ Concepción, Casilla 160-C, Concepción, Chile. eduhernandez@udec.cl \\ ${ }^{2}$ Centro de Investigación Oceanográfica en el Pacífico Sur Oriental (COPAS), Universidad de Concepción, Casilla 160-C, \\ Concepción, Chile \\ ${ }^{3}$ Departamento de Oceanografía, Facultad de Cs. Naturales y Oceanográficas, Universidad de Concepción, Casilla 160-C, \\ Concepción, Chile
}

\begin{abstract}
Resumen.- La ocurrencia de hipoxias naturales y las áreas marinas costeras afectadas por hipoxias antropogénicas se han incrementando en las últimas décadas. En Coliumo, una pequeña bahía somera del Pacífico sur-este, se registró un intenso evento de hipoxia natural en enero del 2008, provocando una mortalidad masiva de peces y otros componentes de la comunidad bentónica y pelágica. En el corto plazo ( 3 meses) se observó una recuperación en la riqueza y densidad total de peces, sin embargo, en el mediano plazo ( 2 años) este evento tuvo efectos negativos en sus tamaños poblacionales. En particular Aphos porosus, especie dominante del ensamble de peces en los fondos blandos de Bahía Coliumo, presentó una disminución progresiva en su tamaño poblacional luego del evento, asociada a una disminución en el reclutamiento. Nuestra hipótesis es que la reducción del tamaño poblacional, habría disminuido la probabilidad de encuentro de adultos reproductivos, disminuyendo huevos, larvas y finalmente los reclutas, llevando a $A$. porosus hacia un umbral crítico de baja densidad, favoreciendo una condición poblacional de efecto Allee. Estos resultados entregan evidencia sobre la relación de causalidad entre eventos de hipoxia natural, mortalidad masiva, historia de vida y dinámica poblacional. La lenta recuperación numérica de $A$. porosus sugiere un proceso en el cual la población presenta una alta vulnerabilidad a nuevas perturbaciones. Esta respuesta poblacional es un ejemplo de la trayectoria que ciertas especies pudieran seguir ante el incremento de eventos de hipoxia natural, el cual se estima podría ocurrir en un escenario de calentamiento global.
\end{abstract}

Palabras clave: Peces, surgencia, hipoxia, efecto Allee, Sistema de Corriente Humboldt

Abstract.- The occurrence of natural hypoxic events and coastal marine areas affected by anthropogenic hypoxia has increased over the past decades. In Coliumo Bay, a small shallow bay of the eastern South Pacific, an intense event of natural hypoxia took place in January 2008, causing the mass mortality of fish and other components of the benthic and pelagic communities. In the short term (3 months) recovery was observed in species richness as well as in total fish density. Nevertheless, in the medium term ( 2 years), this event produced negative effects on population size. In particular, the toadfish Aphos porosus, a dominant fish species in Coliumo Bay, showed a progressive decrease in population size since the occurrence of the hypoxic event, associated with a decrease in recruitment. We hypothesized that this reduction in population size lowered the probability of encounter of reproductive adults, decreasing the number of eggs, larvae and ultimately recruits, thus driving the population towards a low density threshold, and eventually, favoring an Allee effect condition. These results provide evidence on the causal relationship between coastal natural hypoxic events, mass mortality, life history and population dynamics. The slow recovery of the $A$. porosus population size suggests a process in which the population remains vulnerable to new perturbations. The observed population response is an example of the trajectory that some species may follow when faced with increasing occurrences of natural hypoxic events as predicted, for instance, by global warming scenarios.

Key words: Fish, upwelling, hypoxia, Allee effect, Humboldt Current System 


\section{INTRODUCTION}

The frequency of environmental hypoxic events and the total coastal area affected by hypoxia worldwide have increased over the past decades (Díaz \& Rosenberg 2008, Breitburg et al. 2009). Rabalais et al. (2010) described two origins for the generation of hypoxic water masses: (1) Human-caused and (2) naturally-caused. The former is associated with processes of coastal eutrophication, mainly due to the discharge into the coastal ocean of continental waters with high nutrient and organic matter loads. These human-caused hypoxias, in which dissolved oxygen is consumed mostly by prokaryote metabolism, are fairly common and widely studied, including their effects on populations and communities (Rabalais et al. 2010 and references therein, Fleddum et al. 2011, Kodama \& Horiguchi 2011). The naturally-caused hypoxias, which are due principally to the photosynthetic generation of carbon and the associated microbial respiration, are related to permanently hypoxic water masses in the open ocean, referred to as Oxygen Minimum Zones (OMZ) (Helly \& Levin 2004). The entrance of these oxygen-deficient waters into coastal areas due to upwelling processes (Giesecke \& González 2004, Pavez et al. 2006, Sobarzo et al. 2007) may ultimately generate hypoxic conditions (Rabalais et al. 2010 and references therein). These upwelling-driven hypoxic events have been poorly documented and their chronic effects on population and community levels are unknown (but see Grantham et al. 2004, Hernández-Miranda et al. 2010, 2012).

In Coliumo Bay, a small shallow bay off central-south Chile, an intense hypoxic event was recorded in austral summer 2008, causing the mass mortality of fish (Hernández-Miranda et al. 2010) and other epibenthic and demersal taxa (Hernández-Miranda et al. 2012). The instantaneous effects on the fish assemblage were dramatic, with an abrupt drop in total density, total biomass and species richness, which was consistent with the conclusion of Vaquer-Sunyer \& Duarte (2008) who, based on an extensive literature review suggested that fish are the group of organisms most affected by environmental hypoxia conditions. Nevertheless, in the short term (almost 3 months), partial recovery was observed in richness and total density (HernándezMiranda et al. 2010). Despite this, questions emerge regarding the recovery of fish assemblages in the long term (Hernández-Miranda et al. 2012). In addition, how might have this hypoxia affected each particular species?

In the epibenthic macrofaunal community inhabiting the soft-bottom benthos of Coliumo Bay, the toadfish
Aphos porosus (Valenciennes, 1837) (Batrachoididae) is the dominant fish species (Hernández-Miranda et al. 2010) and is the fourth dominant species in relation to the total density and total biomass of the whole community (Hernández-Miranda et al. 2012). The family Batrachoididae has a wide distribution in the Atlantic, Indian and Pacific Oceans (Nelson 1994), mainly inhabiting hard and soft bottoms in shallow marine coastal environments (Varas \& Ojeda 1990, Merlo et al. 2005, Canto-Maza \& VegaCendejas 2007). These species are characterized by solitary and cryptic habits, parental care and larvae without a pelagic life stage (Nelson 1994). Although the members of this family are made up of species with no commercial value (Palazón-Fernández et al. 2010), they are recognized as important components of ichthyofauna communities in the coastal ecosystems they inhabit (Canto-Maza \& Vega-Cendejas 2007, Cortés \& Muñoz 2008). Historically, toadfish species have been used in laboratory studies in the field of endocrinology (Hoffman 1963), physiology (Fänge \& Wittenberg 1958, Haschemeyer 1969) and animal toxicology (Alquezar et al. 2006), among others, and there are increasing efforts to improve knowledge of their basic biology and ecology (Price \& Mensinger 1999, Palazón-Fernández et al. 2001, 2010; Palazón et al. 2003, Malca et al. 2009).

Of the 69 species that make up the Batrachoididae family (Nelson 1994), only A. porosus is found off the coast of Chile (Mann 1954, Pequeño 1989), with a distribution that extends from Puerto Pizarro (Perú) to the Strait of Magellan (Chile) (Chirichigno 1974). The ecological knowledge of $A$. porosus is scarce and mostly consists of reports on spatial and bathymetric distribution (Sielfeld \& Vargas 1999, Ojeda et al. 2000), studies of coastal ichthyofauna (Varas \& Ojeda 1990, Sielfeld \& Vargas 1996, Medina et al. 2004), parasitological studies (Cortés \& Muñoz 2008), and as part of the by-catch of industrial (Lillo et al. 2002) and artisanal common hake (Merluccius gayi gayi) fisheries (Acuña et al. 2007). Up to now, in central-south Chile there is no information about its population dynamics, spatial distribution, habitat selectivity or age at sexual maturity. However, Cortéz \& Muñoz (2008) based on the study of the infra-community of parasites of $A$. porosus, suggested that the habitat of the species was demersal and that this fish could be a prey of other demersal fishes, cetaceans, elasmobranches and sea lions. A. porosus is a predator of small gastropods, fish, amphipods and gamariids (Varas \& Ojeda 1990, Cortéz \& Muñoz 2008), and therefore a consumer of intermediate trophic level or secondary consumer. 
In relation to the effects of the natural hypoxic event on A. porosus in Coliumo Bay, we hypothesized that the intense hypoxic event triggered negative lagged effects over time in A. porosus, leading to a small and critical population size. Given the characteristics of the life history of this species, the recovery could be slow and probably set the population near an Allee threshold (Stephens et al. 1999, Berec et al. 2006). The main objective of this study was to assess the inter-annual effects of hypoxia on the population of $A$. porosus inhabiting the soft-bottom benthos in Coliumo Bay. For this, we (i) evaluate the inter-annual dynamics of density and biomass; (ii) identify the inter-annual recruitment dynamics; (iii) discuss the results in the context of an Allee effect and its ecological implications.

\section{MATERIALS AND METHODS}

\section{STUDY AREA AND DATA COLLECTION}

Coliumo Bay (36 $30^{\circ}$ 'S, $72^{\circ} 56^{\prime}$ W, Fig. 1) is a small, shallow, equator-facing bay with depths under $25 \mathrm{~m}$, characterized mainly by sandy bottoms. A. porosus captures were carried out at 3 sampling stations within Coliumo Bay aproximately every 3 months. The surveys were conducted in January, May, August and November 2007; January, April, July and October 2008 and 2009 and January 2010. Sampling was carried out using a modified Agassiz trawl ( $1 \mathrm{~m}$ wide $\times 1 \mathrm{~m}$ long $\times 30 \mathrm{~cm}$ high, lined with $5 \mathrm{~mm}$ "knot to knot" netting); on the average the survey distance for the whole sampling period was $378 \mathrm{~m} \pm 145 \mathrm{~m}$ trawling for 5 min to $1.5-2$ knots. Fish were collected directly from the net onboard and put in plastic bins with seawater. In the laboratory all individuals were measured (LT: $0.1 \mathrm{~cm}$ precision) and weighed using an analytic precision scale (MT: $0.01 \mathrm{~g}$ precision). All surviving fish were then returned to their environment. A. porosus density (ind. $500 \mathrm{~m}^{-2}$ ) and total biomass (g $500 \mathrm{~m}^{-2}$ ) was calculated by standardizing the quantity and biomass of organisms captured in each tow in relation to the swept area (e.g., $\mathrm{N}^{\circ}$ ind. $\times 1 \mathrm{~m}$ wide trawl $\times 500 \mathrm{~m} /$ Survey distance $\mathrm{m})$. Vertical hydrographic profiles for each sampling period (temperature, salinity and dissolved oxygen) were sampled using a CTDO Sensor Data Model SD204. Data were collected as part of the periodic monitoring program set up by the Programa de Investigación Marina de Excelencia (PIMEX) at Universidad de Concepción (UDEC), Chile. The sampling was carried out using UDEC's research vessels R.V. Kay-Kay I or R.V. KayKay II.

\section{SPECIAL A. POROSUS SAMPLING}

On January 3, 2008, dead and dying fish were collected from Coliumo Bay (Fig. 1). 396 individuals of A. porosus were sampled from a sandy, rocky intertidal zone in front of Villarrica Cove, Dichato in Coliumo Bay (see HernándezMiranda et al. 2010). In the laboratory, for each individual the following measurements were recorded: total length (LT: $0.1 \mathrm{~cm}$ precision), total weight (MT: $0.01 \mathrm{~g}$ precision), sex, gonad weight (MG: $0.01 \mathrm{~g}$ precision), and state of sexual maturity (MS). For MS, a 5-stage visual scale was used following Holden \& Raitt (1975): MS I (immature), MS II (in maturation), MS III (mature), MS IV (hydrated) and MS V (spawned).

a)

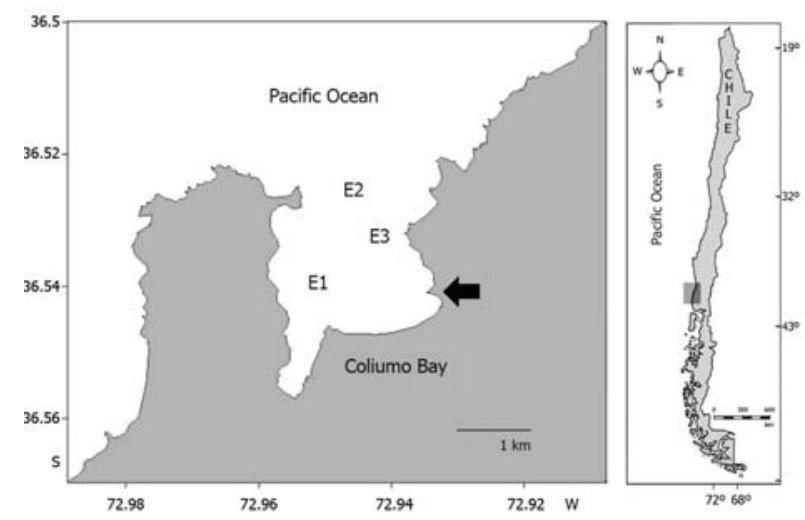

b)

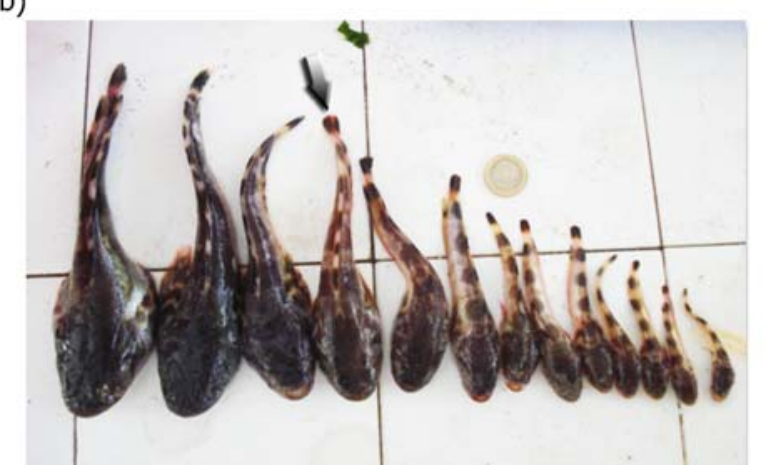

Figure 1. (a) Sampling stations within Coliumo Bay. E1, E2 and E3 correspond to the periodical sampling stations and the black arrow marks the area where the mass stranding of fish was recorded in January 2008. (b) Photographs of the stranded toadfish $A$. porosus in January 2008. The arrow shows the juvenile-adult threshold / (a) Estaciones de muestreo dentro de Bahía Coliumo. E1, E2 y E3 corresponden a las estaciones periódicas de muestreo y la flecha negra señala el lugar de muestreo durante la varazón de enero del 2008. (b) Fotografías de $A$. porosus varados en enero de 2008. La flecha señala el umbral entre individuos juveniles y adultos 


\section{Data analysis}

From the 396 individuals of $A$. porosus collected during the stranding event that took place on January 3, 2008, the following information was obtained: (i) size structure of juveniles, males and females at intervals of $1 \mathrm{~cm}$ length, expressed as percentage frequency; (ii) the fit for the length-mass relationship: MT $=a^{*} \mathrm{LT}^{b}$, where $a$ and $b$ are fitted parameters describing the allometric relationship between these variables. The fit was determined via a least squares non-linear regression, using the NONLIN module in the statistical software package SYSTAT (Wilkinson 1988); (iii) the frequency of occurrence of maturity stage (MS) for both sexes expressed as a percentage. For the analysis, juvenile individuals and MS I and II were considered immature, and MS III and IV were considered mature; (iv) the gonadosomatic index (IG), for reproductive tissue growth. For this the following expression was used: IG $=(\mathrm{MG} /(\mathrm{MT}-\mathrm{MG}))^{*} 100$; (v) the average size at sexual maturity $\left(l_{50 \%}\right)$. For this parameter a logistic model was adjusted according to: $\mathrm{P}_{(l)}=1 /$ $\left(1+e^{\beta 1+\beta 2^{*}}\right)$, where: $\mathrm{P}_{(l)}$ is the mature proportion at size $l$, and $\beta_{1}$ and $\beta_{2}$ are the position and slope parameters, respectively; the average size at sexual maturity is defined as $l_{50 \%}=-\left(\beta_{1} / \beta_{2}\right)$. For the fitting of the logistic model, maximum likelihood was used according to Roa et al. (1999).

The segregation of juvenile from adult stages for the entire sampling period (January 2007- January 2010) was performed according to the average size at sexual maturity obtained during the stranding event (see HernándezMiranda et al. 2010). In addition to the time series of densities, the temporal dynamics of the numerical frequency of body sizes was obtained using the ELEFAN analysis (Gayanilo \& Pauly 1997) of the FiSAT II FAOICLARM Fish Stock Assessment Tools Software. This allowed us to obtain graphically periods of arrival of smaller-sized individuals (i.e., recruitment), an analysis that has already been used for intertidal fish in central Chile (Hernández-Miranda \& Ojeda 2006).

For the entire time series of $A$. porosus catches, the length-mass relationship between calendar years, between cohorts and for the periods prior and after the mortality event were estimated using an algorithm similar to the one utilized for fish collected in the mortality event of January 2008. For this, individuals were pooled as follows: (i) January to November 2007, January 2008 (mortality event), and April 2008 to January 2010, (ii) for the calendar years 2007, 2008 and 2009 and (iii) for each cohort identified according to its recruitment period based on the ELEFAN analysis. The differences between these relationships were analyzed with the slope test (Zar 1999). Based on these relationships, the relative condition factor (Kr) was estimated according to Le Cren (1951) and applied to toadfish following Palazón-Fernández et al. (2001). Kr was calculated as the percentage ratio of the observed weight of a fish to the weight expected from the calculated length-weight relationship. This factor was obtained for 3 calendar years, for each one of the cohorts identified and for the pre- and post-mortality periods. After testing for the assumptions of normality and homogeneity of variances, $\mathrm{Kr}$ values were compared with a one-way ANOVA.

\section{Results}

\section{HYDROGRAPHIC DYNAMICS}

The hypoxic event at Coliumo Bay that took place in January 2008 was characterized by low temperature $\left(<11^{\circ} \mathrm{C}\right)$, increment of salinity in the surface stratum $(>34)$ and very low dissolved oxygen concentration in the whole water column including the surface stratum $(0-1 \mathrm{ml}$ $\mathrm{l}^{-1}$ close to $2 \mathrm{~m}$ deep) (Fig. 2, see Hernández-Miranda et al. 2010, 2012). Coliumo Bay during the sampling dates in January 2009 and January 2010 also showed the presence of Equatorial Subsurface Waters (ESSW) (i.e., temperatures near to $11-12^{\circ} \mathrm{C}$ and salinities higher than 34 at the bottom of the water column), however, dissolved oxygen concentrations were greater than $2 \mathrm{ml} \mathrm{l}^{-1}$ in the surface stratum. This indicated that hypoxic conditions were not observed in both periods.

\section{REPRODUCTIVE AND BIOLOGICAL PARAMETERS}

The size structure of $A$. porosus individuals collected from Coliumo Bay during the massive stranding was unimodal and was composed of 376 juveniles (95.0\%), 14 males (3.5\%) and 6 females (1.5\%). The size range was 5.2-15.2 cm LT, 8.1-15.3 cm LT, and 13.1-19.5 in juveniles, males and females, respectively (Fig. 3a). For individuals with development of reproductive structures $(n=20)$, the male:female ratio was $2: 1$. Ninety three percent $(n=13)$ of males were immature (MS I) and 7\% ( $\mathrm{n}=1)$ in maturation (MS II); while $50 \%$ of females were mature (MS III, $n=3$ ) and $50 \%$ hydrated (MS IV, $n=3$ ). In immature and maturing males and immature females the average IG was less than $2 \%$, while in hydrated females ovaries represented between $32 \%$ and $40 \%$ of body weight, with an average IG of $37 \%$. In general terms, the IG and MS increased in larger individuals (Fig. 3b). For the construction of the 


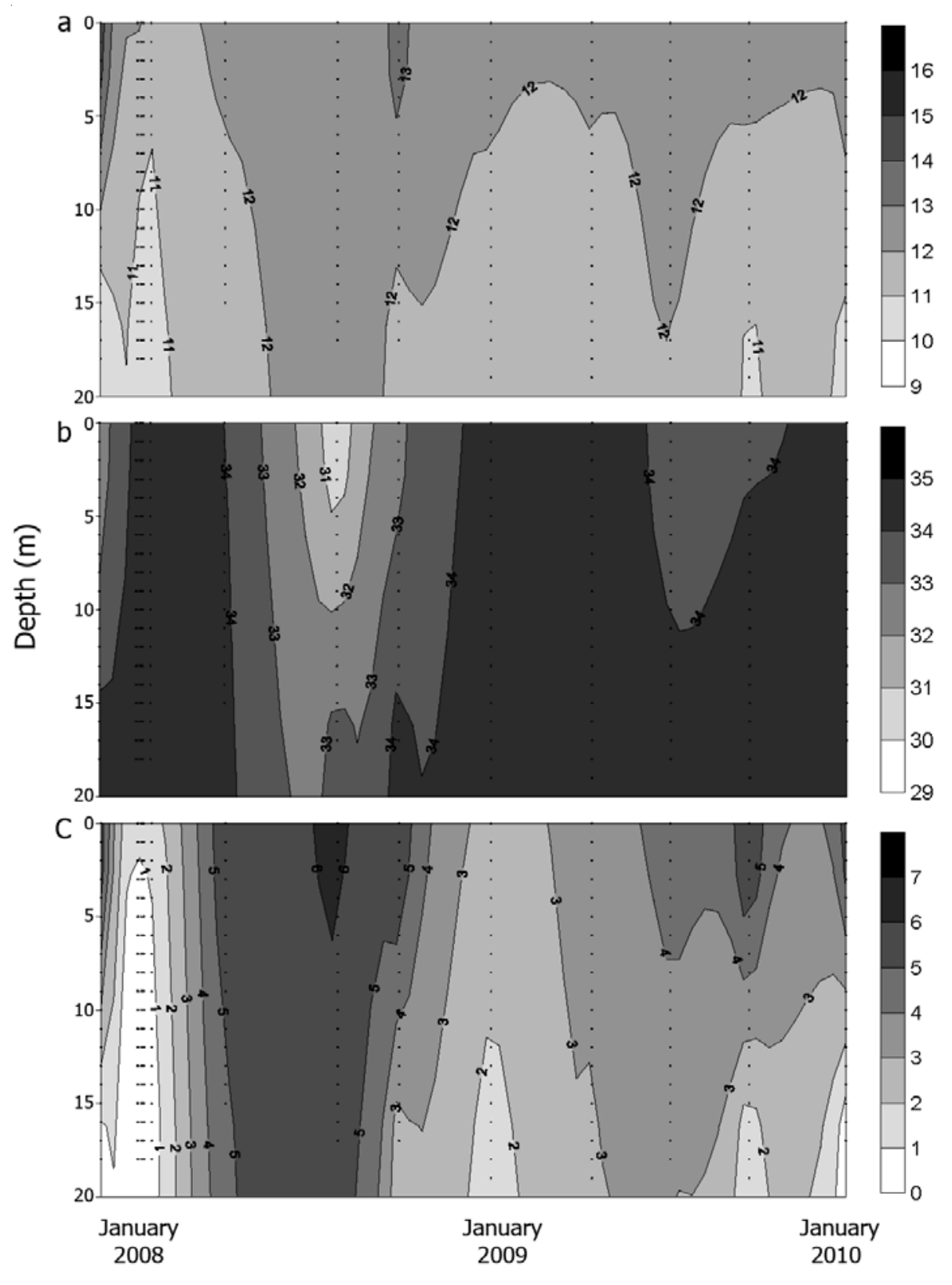

Figure 2. Temporal series of (a) temperature $\left({ }^{\circ} \mathrm{C}\right)$, (b) salinity, and (c) dissolved oxygen $\left(\mathrm{ml} \mathrm{l}^{-1}\right)$ for the entire water column in the period November 2007-January 2010 / Series temporales de (a) temperatura $\left({ }^{\circ} \mathrm{C}\right)$, (b) salinidad, y $(\mathrm{c})$ oxígeno disuelto $\left(\mathrm{ml} \mathrm{l}^{-1}\right)$ en la columna de agua para el período noviembre 2007- enero 2010 

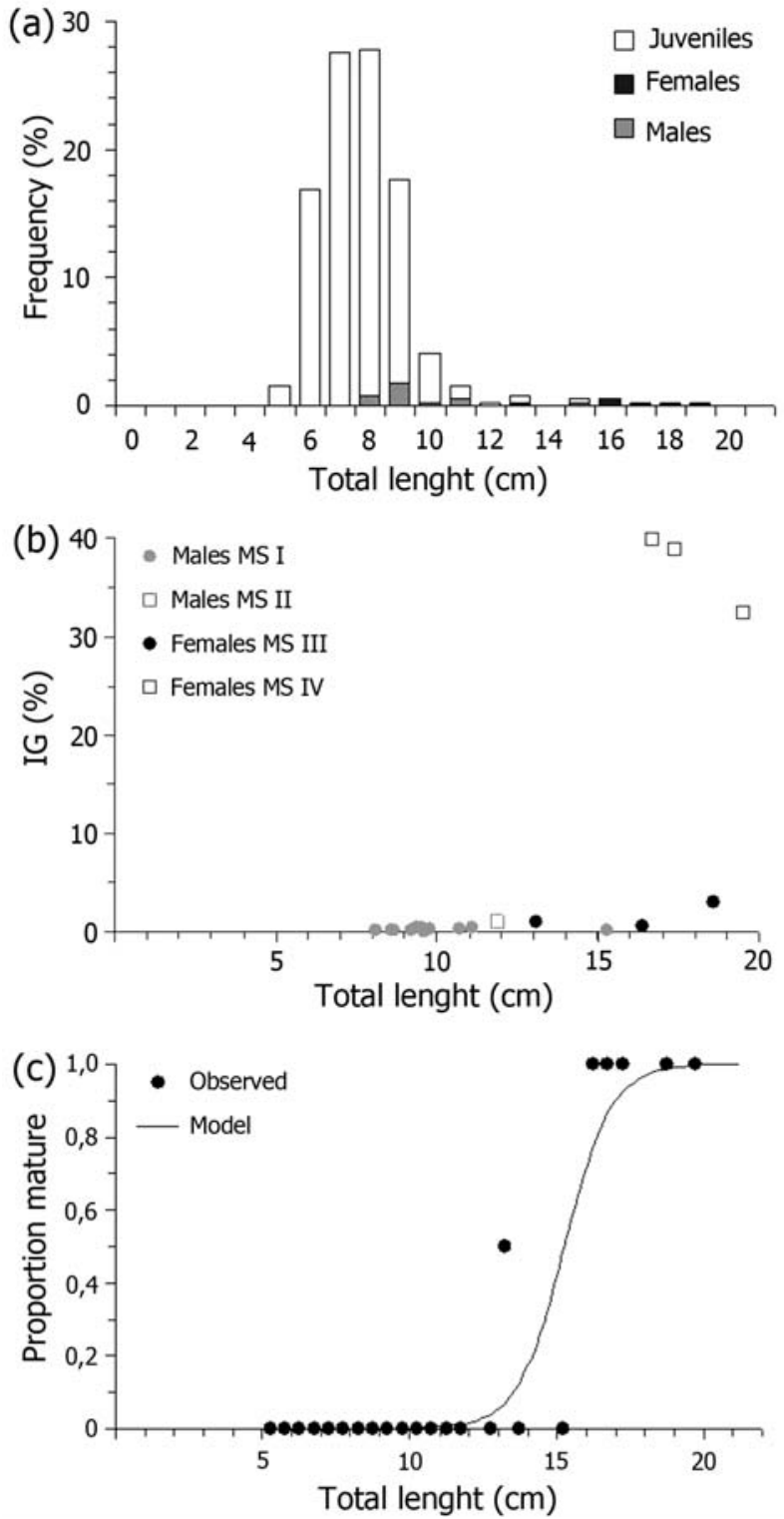

Figure 3. (a) The proportion of juveniles and adults of $A$. porosus in Coliumo Bay during the stranding event of January 2008. (b) Average gonadosomatic index (IG) per maturity stage for males $(n=14)$ and females $(n=6)$ of $A$. porosus during the stranding in January 2008. (c) Sexual maturity ogive for both sexes combined, observed $(\cdot)$ and estimated (-) / (a) Proporción de individuos juveniles y adultos de A. porosus en Bahía Coliumo durante la varazón de enero del 2008. (b) Índice Gonadosomático (IG) promedio por estado de madurez para machos $(n=14)$ y hembras $(n=6)$ de $A$. porosus durante la varazón de enero de 2008. (c) Ojiva de madurez sexual combinado para ambos sexos, observado $(\cdot)$ y estimado $(-)$ maturity ogive, information from both sexes and juveniles was used. The parameters of the logistic model adjusted to the mature proportion data were $\beta_{1}=19.46( \pm 2.34 \mathrm{SE})$ and $\beta_{2}=-1.27$ ( $\left.\pm 0.16 \mathrm{SE}\right)$, with the average size at sexual maturity $\left(l_{50 \%}\right)$ calculated at $15.3 \mathrm{~cm}$ LT (Fig. 3c).

\section{SPATIAL AND TEMPORAL DYNAMICS}

The spatial density of $A$. porosus during the whole sampling period was highly heterogeneous, but it was lowest immediately after the hypoxic event (Fig. 4). In relation to body sizes, between January 2007 and January 2010 A. porosus presented 3 recruitment events (May 2007, April 2008, July 2009); (Fig. 4a), all of individuals close to 4 $\mathrm{cm}$. Three cohorts were identified using the FiSAT II software (Fig. 4a). Temporally, one year after the hypoxic event a recovery in average density and biomass was observed (relative to the hypoxic event), but without reaching the high values observed during the pre-hypoxia period (Fig. 4b, c). The average density in 2007 was 96.98 ( \pm 93.92 SD) individuals $500 \mathrm{~m}^{-2}$, in $200825.82( \pm 33.17 \mathrm{SD})$ individuals $500 \mathrm{~m}^{-2}$ and 200913.6 ( \pm 13.74 SD) individuals $500 \mathrm{~m}^{-2}$. The ANOVA showed significant differences between the 3 periods $\left(\mathrm{F}_{(2,11)}=4.256, P=0.025\right)$. The $a$ posteriori tests indicated that the differences were between the densities from 2007 and 2009, and 2007 and 2008 (Tukey HDS, $P<0.05$ ). The average biomass in 2007 was 195.94 ( \pm 215.03 SD) g $500 \mathrm{~m}^{-2}$, in 200864.48 ( $\pm 63.08 \mathrm{SD}$ ) g $500 \mathrm{~m}^{-2}$ and $200947.62( \pm 47.46 \mathrm{SD}) \mathrm{g} 500 \mathrm{~m}^{-2}$. The ANOVA showed significant differences between the 3 periods $\left(\mathrm{F}_{(2,11)}=\right.$ 4.256, $P=0.072$ ). The a posteriori tests indicated that the differences were between the biomass from 2007 and 2009, and 2007 and 2008 (Tukey HDS, $P<0.1$ ).

Based on the average size at sexual maturity calculated in this study (15.3 cm, see Fig. 3c), we observed a majority of juveniles during all study periods. Adults were captured during only 3 sampling events (Nov. 2007: 0.32\%; Jul. 2008: 15.78\%; Jan. 2010: 25.00\%). For the length-mass relationship, significant differences were encountered between slopes before and after the mortality event relative to that estimated for stranded fish in January 2008 (Fig. 5a) (ANOVA $F_{(2,1392)}=11.89, P<0.001$ ). These differences are due to a steeper slope during the mortality event $(b=3.22)$ relative to estimates for the before $(b=$ $2.98)$ and after $(b=3.03)$ periods (Tukey HDS, $P<0.05)$. Differences were significant between the slopes for the 3 calendar years (Fig. 5b) ANOVA F $_{(2,1000)}=11.44, P<$ $0.001)$. These differences are due to a steeper slope during $2009(b=3.17)$ relative to $2007(b=2.98)$ and $2008(b=$ 2.95) (Tukey HDS, $P<0.05)$. For the length-mass 

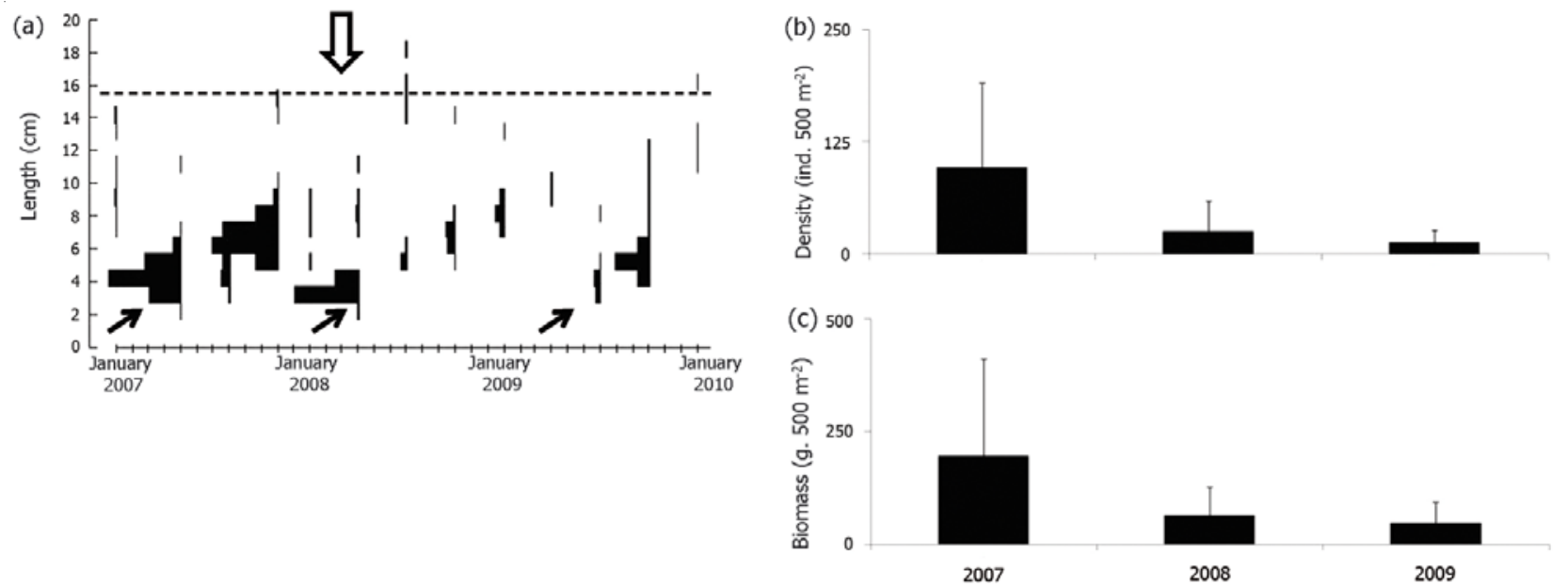

Figure 4. (a) Time series of size frequencies (LT). Black arrows indicate 3 recruitment events and the start of each new cohort. The dashed horizontal lines mark size at sexual maturity estimated for $A$. porosus. The white arrow indicates sampling immediately after the hypoxia event in January 2008. (b) Time series of the mean density and (c) biomass of $A$. porosus in Coliumo Bay, from January 2007 to January 2010 . Verticals bars indicate standard deviation (SD) / (a) Serie temporal de frecuencias de tamaño (LT). Las flechas negras señalan tres eventos de reclutamiento y el inicio de cada nueva cohorte. La línea horizontal segmentada señala el tamaño de madurez sexual estimado para $A$. porosus. La flecha blanca señala el muestreo inmediatamente después de la hipoxia natural de enero del 2008. (b) Serie temporal de la densidad y biomasa promedio (c) de A. porosus en Bahía Coliumo desde enero 2007 hasta enero 2010. Las barras verticales señalan la desviación estándar (DS)
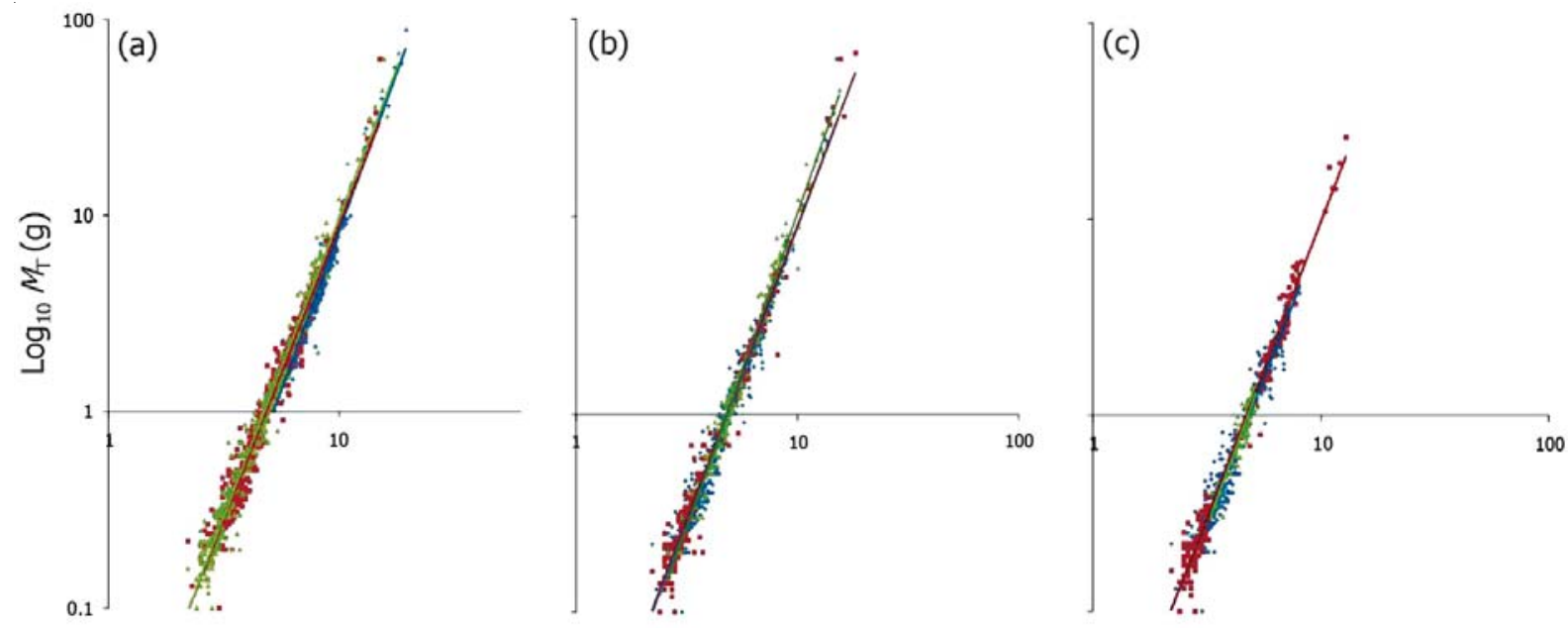

$$
\log _{10} L_{\top}(\mathrm{cm})
$$

Figure 5. Length (LT) and total mass (MT) relationship $\left(\log _{10}-\log _{10}\right.$ scale) for $A$. porosus. (a) Blue marks: stranded fish; red marks: fish captured before natural hypoxia; green marks: fish captured after natural hypoxic event. (b) Blue marks: fish captured during 2007; red marks: fish captured during 2008; green marks: fish captured during 2009. (c) Blue marks: 10 cohort; red marks: 20 cohort; green marks: 30 cohort (see Fig. 5a) / Relación entre el tamaño corporal (LT) y biomasa (MT) (escala $\log _{10}-\log _{10}$ ) para A. porosus. (a) Marcas azules: peces varados; Marcas rojas: peces capturados antes de la hipoxia natural; Marcas verdes: peces capturados después de la hypoxia natural. (b) Marcas azules: peces capturados durante 2007; Marcas rojas: peces capturados durante 2008; Marcas verdes: peces capturados durante 2009. (c) Marcas azules: $1^{\text {a }}$ cohorte; Marcas rojas: $2^{\text {a }}$ cohort; marcas verdes: $3^{\text {a }}$ cohorte (Ver Fig. $5 a$ ) 
relationships per cohort, no significant differences were found between slopes (ANOVA $F_{(2,737)}=2.20, P>0.1$ ), with values of $b=2.92$ (cohort 1 ), $b=2.99$ (cohort 2 ) and $b=3.16$ (cohort 3) (Fig. 5c).

With regard to the factors of relative condition $\mathrm{Kr}$, no significant differences were found between estimated $\mathrm{Kr}$ values before $(\mathrm{Kr}=1.014 \pm 0.178 \mathrm{SD})$ and after the mortality $(\mathrm{Kr}=1.013 \pm 0.197 \mathrm{SD})$, relative to the stranded fish in January $2008(\mathrm{Kr}=1.001 \pm 0.110 \mathrm{SD})\left(\operatorname{ANOVA~F}_{(2,1392)}=\right.$ $0.94, P=0.39)$. Nor were there significant differences among $\mathrm{Kr}$ estimates for calendar years $(\mathrm{Kr} 2007=1.014 \pm$ 0.178 SD; Kr $2008=1.025 \pm 0.213$ SD; Kr $2009=1.019 \pm$ $0.168 \mathrm{SD}$ ) (ANOVA $\mathrm{F}_{(2,1000)}=0.28, P=0.75$ ), or for $\mathrm{Kr}$ estimates per cohort (Kr cohort $1=1.012 \pm 0.179 \mathrm{SD} ; \mathrm{Kr}$ cohort $2=1.022 \pm 0.191 \mathrm{SD} ; \mathrm{Kr}$ cohort $3=1.010 \pm 0.144$ $\mathrm{SD})\left(\right.$ ANOVAF $\left._{(2,737)}=0.21, P=0.81\right)$.

\section{Discussion}

\section{REPRODUCTIVE AND BIOLOGICAL PARAMETERS}

Based on the stranded fish during the natural hypoxia event of January 2008, the average size at sexual maturity, estimated for males and females (pooled), was $15.3 \mathrm{~cm}$. Palazón-Fernández et al. (2001), reported for Halobatrachus didactylus (Batrachoididae; Schneider, 1801) in Cádiz Bay (Spain), that $50 \%$ sexual maturity was reached at $26.2 \mathrm{~cm}$ LT in females and $30.2 \mathrm{~cm} \mathrm{LT}$ in males, associated with sexual dimorphism during growth, a phenomenon also reported for other species of the family Batrachoididae (Malca et al. 2009). More recently, Palazón-Fernández et al. (2010), in another study in Cádiz Bay, reported that this species was able to reach sexual maturity at $19.1 \mathrm{~cm}$ LT (3 years) in females and $16.0 \mathrm{~cm}$ LT (2 years) in males. Palazón-Fernández et al. (2001) suggested that the segregation between juveniles and adults may be above the minimum size at sexual maturity or at least in MS II. Thus, our first approximation for $A$. porosus established the minimum size at sexual maturity at $15.3 \mathrm{~cm} \mathrm{LT}$, within the lower range for toadfish. However, this does not account for possible differences associated with sex.

The soft bottom of Coliumo Bay may be characterized as areas mainly used by recruits and juveniles of $A$. porosus (see Fig. 4a). The absence of adult individuals may be due to their solitary behavior during this ontogenetic stage, in which individuals are territorial and move towards rocky and protected areas to carry out reproduction, where females lay eggs on the rocky substrates of intertidal and subtidal areas, in pools and cracks (Mann 1954, Varas \& Ojeda 1990), thereby facilitating the parental care of fry (Ruiz 1993) characteristic of toadfishes (Amorim et al. 2006).

The occurrence of mature or hydrated females in January 2008 suggests that reproduction and spawning of A. porosus occurs in Coliumo Bay during the austral summer period. Varas \& Ojeda (1990) also reported the presence of egg masses in intertidal pools off central Chile between the period of January to February. The extension of the reproductive period possibly spans spring and summer months, as seen in coastal fish that couple their biological cycles to months of higher primary production (Castro et al. 2000, Hernández-Miranda et al. 2003, 2009). A similar reproductive strategy has been reported for the toadfish H. didactylus (Palazón-Fernández et al. 2001). The marked increase in IG from mature females to hydrated females suggests that once this stage is reached, spawning happens shortly after. This reproductive period is consistent with the presence of smaller-sized individuals in April-May in Coliumo Bay during the 3 autumn seasons sampled (2007, 2008 and 2009). Thus, the reproductive events of $A$. porosus occur mainly in the period January-February, with recruitment following in the period April-May (see Fig. 4a).

\section{NATURAL HYPOXIC EVENT AND ITS IMPLICATIONS}

The occurrence of natural hypoxic events and/or areas affected by hypoxic conditions of anthropogenic origin has increased in recent decades (Díaz \& Rosenberg 2008, Breitburg et al. 2009, Rabalais et al. 2010). Vaquer-Sunyer \& Duarte (2008) concluded that fish and crustaceans are the most sensitive taxa in terms of: (i) the average lethal concentration of oxygen they are able to withstand, (ii) the sublethal threshold of dissolved oxygen, and (iii) the time necessary to generate a negative response (death). Nevertheless, the response of fish populations exposed to natural hypoxic events over longer time scales is still poorly-known (Grantham et al. 2004, Breitburg et al. 2009). The intense event of natural hypoxia in January 2008 affected the entire resident community of Coliumo Bay, causing widespread mortality of organisms and a mass stranding event, with fish being one of the most affected groups (Hernández-Miranda et al. 2010, 2012). These authors reported a recovery in richness of the fish assemblage in a time scale of only 3 months; nevertheless, densities reached only about half their previous level. At a longer time scale negative effects on the total density of the fish assemblage, including A. porosus, were also detected. A similar response pattern was detected in a 
reef fish assemblage exposed to hypoxia due to coral spawn 'slicks' off Coral Bay in Western Australia (Halford \& Perret 2009).

From an ontogenetic point of view, the greatest percentage of dead individuals of $A$. porosus during the hypoxic event were juveniles with a mode around $8 \mathrm{~cm}$ (approximately 1 year old; see Fig. $1 \mathrm{~b}$ and $3 a$ ), similar to what occurred in the stranding event occurred in Coliumo Bay in 1989 (Jara 1992). This is consistent with the reported high sensitivity of juvenile fish when exposed to hypoxia (Nilsson \& Östlund-Nilsson 2008). From a physiological point of view, the length-mass relationships allowed us to determine the condition of this segment of the population of A. porosus. Estimations of allometric slopes from 3 analyses (pre and post mortality, interannual and cohorts) demonstrated some significant differences in A. porosus in Coliumo Bay during the massive mortality event in relation to the before and after periods, and in 2009 relative to 2007 and 2008, but not between cohorts. These results, in terms of the cube law for the length-mass relationship (Verdiell-Cubedo et al. 2006), suggest temporal changes in the condition of $A$. porosus within Coliumo Bay. However, in all cases this parameter was within the expected range of variability about a theoretical value of 3. Le Cren (1951) suggested that the relative condition factor $\mathrm{Kr}$ is of greater use in the study of fish condition. This factor corrects possible errors associated with a non-perfect fit of 3 for all fish, which could be caused by, for example, differences in sex, ontogenetic stages and differential fishing gear. The $\mathrm{Kr}$ is not affected by these factors, and results in a better comparative tool (Palazón-Fernández et al. 2001). In the case of $A$. porosus, for the 3 analyses carried out there were no significant differences in $\mathrm{Kr}$. This result suggests that, independent of the density decrease and biomass that took place in Coliumo Bay, the physiological condition of $A$. porosus (mainly juveniles) was normal.

It is important to note that hypoxia may affect differentially some species with particular ecological characteristics, such as low dispersion of early life stages and low mobility in adults. A. porosus displays (i) a low level of dispersion due to larvae that do not possess a planktonic phase, and once hatched tend to remain close to the rocky substrate where eggs were deposited (e.g., Varas \& Ojeda 1990), and (ii) highly territorial adults which carry out parental care during the reproductive period (e.g., Ruiz 1993, Amorim et al. 2006), which leads to a restricted home range. These characteristics suggest that A. porosus has a limited dispersal potential especially during the juvenile life stage, given that this age group inhabits soft bottom environments. Because of this, $A$. porosus requires a longer period of time (probably interannual scale) for juveniles to segregate and colonize new habitats, in contrast to organisms that undergo dispersion via pelagic larvae, which can establish connection between areas on an intra-annual scale or even within days. Thus, it is likely that juveniles outside Coliumo Bay, not affected by the natural hypoxic event, colonized the bay slowly, with a stepping-stone dynamics (e.g., Neal 2004). Individuals that initially survived the natural hypoxia event, or moved to areas not affected by it, were in very low densities, thus decreasing the encounter probability between reproductive males and females, which ultimately would explain the sustained decrease in population size within Coliumo Bay following the January 2008 mortality event. This is further reflected by the cohorts identified from 2007 onwards (see Fig. 4). Decrease in population size in the juvenile fraction of $A$. porosus may cause a time lag of at least 3 years until the recovery of previous population size. This inference is based on the curves of somatic growth (see Fig. 4a), where following a recruitment event the size at sexual maturity was reached approximately 3 years after the recruitment event.

\section{APHOS POROSUS IN A POPULATION CONTEXT}

In the population context, it is probable that following the natural hypoxic event the abundance of $A$. porosus within the bay shifted towards a low or unstable condition (Berryman 1999), further increasing the spatial segregation of individuals, including spawning adults. This underpopulation condition, also known as the Allee effect (Allee 1949, Berryman 2003), may currently dominate A. porosus population dynamics in Coliumo Bay. An Allee effect occurs when the fitness of individuals in a small or dispersed population declines when the size or density of the population decreases (Courchamp et al. 1999, Stephens et al. 1999, Berec et al. 2006). The causal factors are diverse, but according to Courchamp et al. (1999) they may be classified in 3 categories: (1) inbreeding and loss of heterozygosity which cause a reduction in fitness; (2) demographic stochastics, including fluctuations in the proportions of sexes; and (3) reduction in cooperative interaction (obligatory or facultative) when there are few individuals, including reproduction and anti-predator strategies. Operationally, a low reproductive rate will generate low recruitment and successive low rates of reproduction will lead the population to an extinction 
vortex and finally to collapse. The categories mentioned above may act individually or simultaneously as demonstrated by Berec et al. (2006), for instance: (i) difficulty in finding mates when population size or density is low, (ii) when population size decreases, vulnerability to predators increases, and (iii) increase in the selfing rate and/or a decrease in number of matings among small and inbred populations. In the case of A. porosus, given its lack of gregariousness, especially in the adult state, the proposed Allee effect may be associated with protocooperation mechanisms (Courchamp et al. 1999). Here, the effect is evident at the moment of reproduction, in which low population size decreases the rate of encounter among reproductive individuals, reducing the final success of the total reproduction of the population. Below this critical threshold of stability the population trajectory may lead to local extinction as a result of a decline in reproduction, survival or both. In marine environments this has even been documented in benthic invertebrates with pelagic larval stages (Knowlton 1992). However, it is difficult to demonstrate an Allee effect quantitatively (Courchamp et al. 1999). A first step is to identify the mechanisms and factors which cause a population to cross its extinction threshold, for example, due to natural catastrophes (Lande 1993, 1998) in which population sizes are reduced drastically. Courchamp et al. (1999) and Stephens et al. (1999) developed a theoretical mathematical model of population dynamics of the necessary conditions to produce an Allee threshold in which a population is driven to local extinction. We hypothesize that after the hypoxic event the population of Coliumo bay A. porosus appears to have crossed this threshold. The incorporation of the estimated values of population growth for $A$. porosus for the years 2007-2010 in Courchamp et al. (1999) and Stephens et al. (1999)'s model (see Fig. 6) shows that the growth rate of the population after the hypoxia is in the unstable zone and has probably fallen under the extinction threshold.

In the absence of new severe environmental

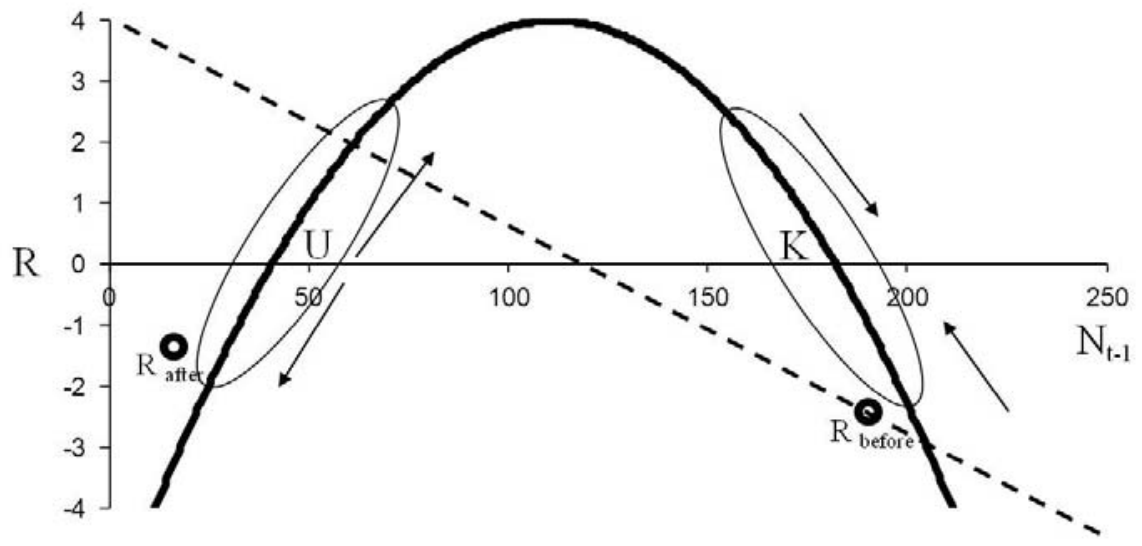

Figure 6. Conceptual model of population dynamics, modified from Courchamp et al. (1999) and Stephens et al. (1999). $\mathrm{R}$ is the realized per capita rate of change of the population. $R=\ln N_{t}-\ln N_{t-1}$ (see Berryman 1999). $N_{t}$ is the density of recruits for the April-May periods of the years 2007, 2008 and 2009. $U$ is the zone of unstable equilibrium or extinction threshold. Below this zone $\left(N_{t}<U\right.$ ) the population may go extinct. $K$ is the zone of stable equilibrium or carrying capacity, in which the population size oscillates around the value $N_{t}=K$. The ellipses indicate the areas of influence of each of the equilibrium points; arrows indicate the most probable direction of $R$ when population size is in these areas. The dashed line corresponds to a theoretical negative linear relationship between $\mathbf{R}$ and population size (classical density-dependent model). The humped curve is a theoretical non-linear relationship between $\mathbf{R}$ and population size (inverse density-dependent model with Allee effect). Circles indicate the calculated $R$ values for the periods 2007-2008 (before hypoxia: $N_{t-1}=184, R=-2.73$ ) and 2008-2009 (After hypoxia: $\mathbf{N}_{t-1}=12, \mathbf{R}=-1.39$ ). Modelo conceptual de dinámica poblacional, modificado a partir de Courchamp et al. (1999) y Stephens et al. (1999). $R$, corresponde a la tasa per cápita de cambio poblacional realizada, donde $R=\ln N_{t}-\ln N_{t-1}$ (Ver Berryman 1999). $N_{t}$, corresponde a la densidad de reclutas para cada periodo abril-mayo de los años 2007, 2008 y 2009. U, corresponde a la zona de equilibrio inestable o umbral de extinción. Bajo esta zona $\left(\mathrm{N}_{\mathrm{t}}<\mathrm{U}\right)$, la población puede llegar a una extinción. $\mathrm{K}$, corresponde a la zona de equilibrio estable o capacidad de carga en donde la población oscila con un tamaño poblacional en torno al valor de $N_{t}=K$. Las elipses señalan las zonas de influencia de cada uno de los puntos de equilibrio y la flechas señalan la dirección más probable que tomará $R$ luego de que el tamaño poblacional se ubique en dichas zonas. La línea segmentada corresponde a una relación negativa teórica lineal entre $\mathrm{R}$ y el tamaño poblacional (modelo clásico de denso-dependencia). La curva jorobada corresponde a una relación teórica no-lineal entre $\mathrm{R}$ y el tamaño poblacional (modelo de denso-dependencia inversa con un efecto Allee). Los círculos señalan los valores de R calculados para los períodos 2007-2008 (Antes de la hipoxia: $N_{t-1}=184, R=-2,73$ ) y 2008-2009 (Después de la hipoxia: $N_{t-1}=12, R=-1,39$ ) 
perturbations the abundance of $A$. porosus population in Coliumo Bay should increase slowly over time. In this recovery, the connectivity of Coliumo Bay and nearby non-affected areas should play a fundamental role.

\section{ACKNOWLEDGMENTS}

This research is part of the Programa de Investigación Marina de Excelencia (PIMEX) of the Faculty of Natural and Oceanographic Sciences of the University of Concepción, funded by Celulosa Arauco and Constitución S. A. The authors wish to thank Mr. Juan Carlos Garrido and the Union of Artisanal Fishermen of Coliumo for their support with the field work during the hypoxic event of January 2008. We thank Alvaro Araneda, Wilfredo Alarcón, Karla Ibáñez and Luis Lozano for their assistance during the sampling program. We thank to the crew of the R/V Kay-Kay II for their field support. We acknowledge two anonymous reviewers for their valued suggestions on how to improve the manuscript.

\section{LITERATURE CITED}

Acuña E, JC Villarroel, M Araya, X Hernández, M Andrade, A Cortés \& J Peñailillo. 2007. Estudio biológico-pesquero de los recursos cabinza, machuelo, sierra y blanquillo en la III y IV Regiones, 247 pp. Informe Final Corregido FIP N ${ }^{\circ}$ 2006-53: 1-247. <http://www.fip.cl/Archivos/Hitos/ Informes/inffinal\%202006-53.pdf>

Allee WC, AE Emerson, O Park, T Park \& KP Schmidt. 1949. Principles of animal ecology, 837 pp. Saunders, Philadelphia.

Alquezar R, SJ Markich \& DJ Booth. 2006. Effects of metals on condition and reproductive output of the smooth toadfish in Sydney estuaries, south-eastern Australia. Environmental Pollution 142: 116-122.

Amorim MCP, RO Vasconcelos, JF Marques \& F Almada. 2006. Seasonal variation of sound production in the Lusitanian toadfish Halobatrachus didactylus. Journal of Fish Biology 69: 1892-1899.

Berec L, E Angulo \& F Courchamp. 2006. Multiple Allee effects and population management. Trends in Ecology and Evolution 22(4): 185-191.

Berryman AA. 1999. Principles of population dynamics and their application, 243 pp. Stanley Thornes, Cheltenham.

Berryman AA. 2003. On principles, laws and theory in population ecology. Oikos 103(3): 695-701.

Bourbeau-Lemieux A, M Festa-Bianchet, J Gaillard \& F Pelletier. 2011. Predator-driven component Allee effects in a wild ungulate. Ecology Letters 14: 358-363.

Breitburg DL, DW Hondorp, LA Davias \& RJ Diaz. 2009. Hypoxia, nitrogen, and fisheries: integrating effects across local and global landscapes. Annual Review of Marine Science 1: 329-349.
Canto-Maza WG \& ME Vega-Cendejas. 2007. Distribución, abundancia y preferencias alimenticias del pez sapo Opsanus phobetron (Batrachoididae) en la laguna costera de Chelem, Yucatán, México. Revista de Biología Tropical 55(3-4): 979-988.

Castro LR, GR Salinas \& EH Hernández. 2000. Environmental influences on winter spawning of the anchoveta Engraulis ringens off central Chile. Marine Ecology Progress Series 197: 247-258.

Chirichigno N. 1974. Clave para identificar los peces marinos del Perú. Informe, Instituto del Mar del Perú. 44: 1-387.

Cortés Y \& G Muñoz. 2008. Infracomunidades de parásitos eumetazoos del bagre de mar Aphos porosus (Valenciennes, 1837) (Actinopterygii: Batrachoidiformes) en Chile central. Revista de Biología Marina y Oceanografía 43(2): 255-263.

Courchamp F, T Clutton-Brock \& B Grenfell. 1999. Inverse density dependence and the Allee effect. Trends in Ecology and Evolution 14(10): 405-410.

Diaz RJ \& R Rosenberg. 2008. Spreading dead zones and consequences for marine ecosystems. Science 321: 926-929.

Fänge R \& JB Wittenberg. 1958. The swimbladder of the toadfish (Opsanus tau L.). The Biological Bulletin 115: 172179.

Fleddum A, SG Cheung, P Hodgson \& PKS Shin. 2011. Impact of hypoxia on the structure and function of benthic epifauna in Tolo Harbour, Hong Kong. Marine Pollution Bulletin 63: 221-229.

Gayanilo FC Jr. \& D Pauly. 1997. The FAO-ICLARM stock assessment tools (FiSAT) reference manual, $262 \mathrm{pp}$. FAO Computerized Information Series (Fisheries), Rome.

Giesecke R \& HE González. 2004. Feeding of Sagitta enflata and vertical distribution of chaetognaths in relation to low oxygen concentrations. Journal of Plankton Research 26(4): 475-486.

Grantham BA, F Chan, KJ Nielsen, DS Fox, JA Barth, A Huyer, J Lubchenco \& B Menge. 2004. Upwelling-driven nearshore hypoxia signals ecosystem and oceanographic changes in the northeast Pacific. Nature 429: 749-754.

Halford AR \& J Perret. 2009. Patterns of recovery in catastrophically disturbed reef fish assemblages. Marine Ecology Progress Series 383: 261-272.

Haschemeyer EV. 1969. Oxygen consumption of temperatureacclimated toadfish, Opsanus tau. The Biological Bulletin 136: 28-32.

Helly JJ \& LA Levin. 2004. Global distribution of naturally occurring marine hypoxia on continental margins. DeepSea Research I 51: 1159-1168

Hernández-Miranda E \& FP Ojeda. 2006. Inter-annual variability in somatic growth rates and mortality of coastal fishes off central Chile: an ENSO driven process? Marine Biology 149: 925-936.

Hernández-Miranda E, AT Palma \& FP Ojeda. 2003. Larval fish assemblages in nearshore coastal waters off central Chile: temporal and spatial patterns. Estuarine, Coastal and Shelf Science 56: 1075-1092. 
Hernández-Miranda E, R Veas, F Labra, A Araneda, FD Carrasco, M Salamanca, JM Rojas \& R Quiñones. 2009. Biodiversidad del ecosistema costero adyacente a la desembocadura del Río Itata. En: Parra O, JC Castilla, H Romero, RA Quiñones \& A Camaño (eds). La cuenca hidrográfica del Río Itata: Aportes científicos para su gestión sustentable, pp. 143-159. Editorial Universidad de Concepción, Concepción.

Hernández-Miranda E, RA Quiñones, G Aedo, A Valenzuela, N Mermoud, C Román \& F Yañez. 2010. A major fish stranding caused by a natural hypoxic event in a shallow bay of the eastern South Pacific Ocean. Journal of Fish Biology 76: 1543-1564.

Hernández-Miranda E, R Veas, FA Labra, M Salamanca \& RA Quiñones. 2012. Response of the epibenthic macrofaunal community to a strong upwelling-driven hypoxic event in a shallow bay of the southern Humboldt Current System. Marine Environmental Research 79: $16-28$

Hoffman RA. 1963. Gonads, spermatic ducts, and spermatogenesis in the reproductive system of male toadfish, Opsanus tau. Coastal and Estuarine Research Federation 4: 21-29.

Holden MJ \& DFS Raitt. 1975. Manual de Ciencia Pesquera. Parte 2.- Métodos para investigar los recursos y su aplicación. ONU/FAO Documento Técnico de Pesca 115, Rev. 1: 1-255.

Jara F. 1992. Composición específica y tamaños de la ictiofauna proveniente en una arribazón en Dichato (36³2's; 7357’W), Concepción, Chile. Investigación Pesquera, Chile 37: 127-132.

Knowlton N. 1992. Thresholds and multiple stable states in coral reef community dynamics. American Zoologist 32(6): 674-682.

Kodama K \& T Horiguchi. 2011. Effects of hypoxia on benthic organisms in Tokyo Bay, Japan: A review. Marine Pollution Bulletin 63: 215-220.

Lande R. 1993. Risks of population extinction from demographic and environmental stochasticity and random catastrophes. American Naturalist 142(6): 911-927.

Lande R. 1998. Demographic stochasticity and Allee effect on a scale with isotropic noise. Oikos 83: 353- 358.

Le Cren E. 1951. The length-weight relationship and seasonal cycle in gonad weight and condition in the perch (Perca fluviatilis). Journal of Animal Ecology 20: 201-219.

Lillo S, S Núñez, V Ojeda, F Balbontin, M Braun, R Tascheri, A Saavedra, R Bravo, J Ortiz, P Torres, L Cubillos \& J Olivares. 2002. Evaluación hidroacústica de merluza común. Informe Final Proyecto FIP 2001-18: 1-167. <http://www.fip.cl/Archivos/Hitos/Informes/ inffinal\%202001-18.pdf>

Malca E, JF Barimo, JE Serafy \& PJ Walsh. 2009. Age and growth of the gulf toadfish Opsanus beta based on otolith increment analysis. Journal of Fish Biology 75: 1750-1761.
Mann G. 1954. Vida de los peces en aguas chilenas, 343 pp. Instituto Investigaciones Veterinarias y Universidad de Chile, Santiago.

Medina M, MAraya \& A Vega. 2004. Alimentación y relaciones tróficas de peces costeros de la zona del norte de Chile. Investigaciones Marinas 32: 33-47.

Merlo MA, I Cross, C Sarasquete, JL Palazón-Fernández \& L Rebordinos. 2005. Caracterización cromosómica del pez sapo Halobatrachus didactylus (Schneider, 1801) (Teleostei: Batrachoididae) mediante hibridación in situ de fluorescencia. Boletín del Instituto Español de Oceanografía 21: 239-246.

Neal D. 2004. Introduction to population biology, 393 pp. Cambridge University Press, Cambridge.

Nelson JS. 1994. Fishes of the world, 600 pp. John Wiley \& Sons, New York.

Nilsson GE \& S Östlund-Nilsson. 2008. Does size matter for hypoxia tolerance in fish? Biological Reviews 83: 173-189.

Ojeda FP, FA Labra \& AA Muñoz. 2000. Biogeographic patterns of Chilean littoral fishes. Revista Chilena de Historia Natural 73: 625-641.

Palazón JL, M Nirchio \& C Sarasquete. 2003. Conventional karyotype and nucleolar organizer regions of the toadfish Halobatrachus didactylus (Schneider, 1801) (Pisces: Batrachoididae). Scientia Marina 67: 445-449.

Palazón-Fernández JL, AM Arias \& C Sarasquete. 2001. Aspects of the reproductive biology of toadfish, Halobatrachus didactylus (Schneider, 1801) (Pisces: Batrachoididae). Scientia Marina 65: 131-138.

Palazón-Fernández JL, JC Potts, CS Manooch III \& C Sarasquete. 2010. Age, growth and mortality of the toadfish, Halobatrachus didactylus (Schneider, 1801) (Pisces: Batrachoididae), in the Bay of Cádiz (southwestern Spain). Scientia Marina 74: 121-130.

Pavez MA, LR Castro \& HE González. 2006. Across-shelf predatory effect of Pleurobrachia bachei (Ctenophora) on the small-copepod community in the coastal upwelling zone off northern Chile ( $\left.23^{\circ} \mathrm{S}\right)$. Journal of Plankton Research 28(2): 115-129.

Pequeño G. 1989. Peces de Chile. Lista sistemática revisada y comentada. Revista de Biología Marina 24(2): 1-132.

Price NN \& AF Mensinger. 1999. Predator-prey interactions of juvenile toadfish, Opsanus tau. The Biological Bulletin 197: 246-247.

Rabalais NN, RJ Díaz, LA Levin, RE Turner, D Gilbert \& J Zhang. 2010. Dynamics and distribution of natural and human-caused hypoxia. Biogeosciences 7: 585-619.

Roa R, B Ernst \& F Tapia. 1999. Estimation of size at sexual maturity: evaluation of analytical and resampling procedures. Fishery Bulletin 97: 570-580.

Ruiz VH. 1993. Ictiofauna del Río Andalién (Concepción, Chile). Gayana Zoologia 57: 109-279. 
Sielfeld W \& M Vargas. 1996. Composición y estructura de la ictiofauna demersal en la zona norte de Chile. Investigaciones Marinas, Chile 24: 3-17.

Sielfeld W \& M Vargas. 1999. Review of marine fish zoogeography of Chilean Patagonia $\left(42^{\circ}-57^{\circ} \mathrm{S}\right)$. Scientia Marina 63: 451-463.

Sobarzo M, L Bravo, D Donoso, J Garcés-Vargas \& W Schneider. 2007. Coastal upwelling and seasonal cycles that influence the water column over the continental shelf off central Chile. Progress in Oceanography 75(3): 363-382.

Stephens PA, WJ Sutherland \& RP Freckleton. 1999. What is the Allee effect? Oikos 87(1): 185-190.

Vaquer-Sunyer R \& CM Duarte. 2008. Thresholds of hypoxia for marine biodiversity. Proceedings of the National Academy of Sciences of the United States of America 105(40): 15452-15457.
Varas E \& F Ojeda. 1990. Intertidal fish assemblages of the central Chilean coast: diversity, abundance and trophic patterns. Revista de Biología Marina 25: 59-70.

Verdiell-Cubedo D, FJ Oliva-Paterna \& M Torralva. 2006. Length-weight relationships for 22 fish species of the Mar Menor coastal lagoon (western Mediterranean Sea). Journal of Applied Ichthyology 22: 293-294.

Wilkinson L. 1988. SYSTAT: The system for statistic, Version 4.0 Systat, Evanston.

Zar JH. 1999. Biostatistical analysis, 663 pp. Prentice Hall, Upper Saddle River.

Received 1 June 2012 and accepted 5 November 2012

Associate Editor: Mauricio Landaeta D. 